\title{
Penguatan Fungsi Legeslasi Dewan Perwakilan Daerah Republik Indonesia Dalam Pembahasan Rancangan Undang-Undang
}

\section{Strengthening the Legislative Function of the Regional Representative Council of the Republic of Indonesia in Discussing Draft Laws}

\author{
Ahmad Dediansyah \\ Program Studi Magister Hukum, Fakultas Hukum Universitas Islam Sumatera Utara, Indonesia \\ Diterima: Desember 2019; Disetujui: Desember 2019; Dipublish: Desember 2019 \\ *Coresponding Email: dediansyah@gmail.com
}

\begin{abstract}
Abstrak
Penelitian ini bertujuan untuk mengetahui posisi fungsi dan wewenang Dewan Perwakilan Daerah berdasarkan Undang-Undang Dasar Negara Republik Indonesia Tahun 1945 dan urgensi memperkuat fungsi Dewan Perwakilan Daerah sebagai wakil daerah dalam pembuatan kebijakan nasional di pusat. tingkat. Metode penelitian yang digunakan adalah metode penelitian hukum normatif yang berfokus pada penelitian kepustakaan, yaitu pencarian bahan hukum yang terdiri dari bahan hukum primer, bahan hukum sekunder, dan bahan hukum tersier. untuk mendapatkan data sekunder dari bahan hukum. Pendekatan normatif dilakukan dengan meninjau ketentuan atau regulasi yang berlaku. Pada dasarnya keberadaan Dewan Perwakilan Daerah melalui amandemen Undang-Undang Dasar Negara Republik Indonesia Tahun 1945 didasarkan pada adanya 2 (dua) faktor, yaitu demokratisasi dan upaya mengakomodasi daerah dalam membuat kebijakan nasional, secara teoritis keberadaan Dewan Perwakilan Daerah dimaksudkan untuk menerapkan prinsip checks and balances antar lembaga negara, yaitu proses saling pengawasan dan keseimbangan antar lembaga negara. Hal ini dilakukan untuk memperkuat hubungan pusat dan daerah dalam rangka menjaga integritas dan kesatuan negara kesatuan Republik Indonesia. Namun berdasarkan hasil amandemen Undang-Undang Dasar Negara Republik Indonesia Tahun 1945 kewenangan Dewan Perwakilan Daerah untuk menjalankan fungsinya sebagai wakil daerah masih kurang memadai, sehingga keinginan untuk menerapkan prinsip check and balances antar lembaga Negara masih belum terealisasi.

Kata kunci: Penguatan, Fungsi, Legislasi. Dewan Perwakilan Daerah.
\end{abstract}

\section{Abstract}

This study aims to determine the position of the functions and authority of the Regional Representative Council based on the 1945 Constitution of the Republic of Indonesia and the urgency of strengthening the function of the Regional Representative Council as a regional representative in national policy making at the central level. The research method used is a normative legal research method that focuses on library research, namely the search for legal materials consisting of primary legal materials, secondary legal materials, and tertiary legal materials. to obtain secondary data from legal materials. The normative approach is carried out by reviewing the provisions or regulations in force. Basically, the existence of the Regional Representative Council through an amendment to the 1945 Constitution of the Republic of Indonesia is based on the existence of 2 (two) factors, namely democratization and efforts to accommodate regions in making national policies, theoretically the existence of the Regional Representative Council is intended to apply the principle of checks and balances between state institutions, namely the process of mutual supervision and balance between State institutions. This was done to strengthen central and regional relations in order to maintain the integrity and unity of the unitary state of the Republic of Indonesia. However, based on the amendment results of the 1945 Constitution of the Republic of Indonesia the authority of the Regional Representative Council to carry out its function as a regional representative is still inadequate, so the desire to implement the principle of checks and balances between State institutions is still not realized.

Keywords: Strengthening, Function, Legislation. Regional Representative Council.

How to Cite: Dediansyah, A. (2019). Penguatan Fungsi Legeslasi Dewan Perwakilan Daerah Republik Indonesia Dalam Pembahasan Rancangan Undang-Undang. Journal of Education, Humaniora and Social Sciences (JEHSS). 2 (2): 352-369. 


\section{PENDAHULUAN}

Kedaulatan rakyat adalah merupakan salah satu prinsip ketatanegaraan Indonesia, yang termuat dalam Pembukaan dan Pasal-Pasal UUD Negara Republik Indonesia Tahun 1945. Oleh karena itu, perlu kajian tentang penganutan teori kedaulatan rakyat Indonesia yang tidak hanya merupakan adopsi dari ajaran J.J. Rousseau, tetapi juga bersumber dari nilai-nilai yang hidup dalam diri bangsa Indonesia (volkgeist). "Prinsip kerakyatan yang dipimpin oleh hikmat kebijaksanaan dalam permusyawaratan/perwakilan dalam alinea ke-IV Pembukaan UUD 1945, adalah perkawinan antara asas kerakyatan dalam masyarakat pedesaan yang berintikan pada musyawarah mufakat, dengan ajaran kedaulatan rakyat dari Eropah dan Amerika yang bersendikan pada perwakilan" (Bakar, 1987).

Muhammad Yamin dalam konteks yang demikian berpandangan bahwa pengertian kedaulatan rakyat dalam UUD 1945 berasal dari 2 (dua) aliran pikiran: aliran pertama, adalah lanjutan perkembangan kedaulatan dalam perjalanan sejarah Indonesia, dan aliran kedua merupakan petikan hasil revolusi-revolusi dunia yang bergelora dalam sejarah dunia sejak revolusi Amerika, Prancis dan Rusia (Bakar, 1987). Hikmah kebijaksanaan yang menjadi pimpinan kerakyatan Indonesia ialah rasionalisme yang sehat, karena telah melepaskan dari anarki, liberalisme dan semangat penjajahan (Yamin, 1971). Dalam konstruksi inilah, apabila diperhatikan risalah perumusan UUD 1945, keberadaan MPR sebagai sebuah lembaga dimaksudkan merupakan perwujudan representasi seluruh rakyat Indonesia, dan mempunyai kekuasaan tertinggi di dalam Negara. Akan tetapi berdasarkan hasil Perubahan UUD 1945, keberadaan MPR telah mengalami degradasi, tidak lagi berkedudukan sebagai lembaga pelaksana kedaulatan rakyat (Pasal 1 ayat (2) UUD 1945), dan juga tidak lagi merupakan lembaga tertinggi negara yang akan membagikan kekuasaan secara vertikal kepada lembaga-lembaga negara yang berada di bawahnya (no rival authority), melainkan merupakan lembaga negara yang sederajat dengan lembaga negara lainnya. MPR dalam konteks mewujudkan sendi negara berdasar atas hukum, telah didesign kepada gagasan restrukturisasi parlemen dari "unicameral system" menjadi "bicameral system" yang ditandai dengan adanya kelembagaan Dewan Perwakilan Rakyat (DPR) yang mewakili aspirasi partai politik (political representation), dan Dewan Perwakilan Daerah (DPD) yang mewakili kepentingan daerah (regional representation). Harapannya agar aspirasi konstituen 
lewat partai politik dan yang berkembang di daerah memiliki pintu penyaluran yang komprehensif di parlemen. Bahkan menurut Jimly Asshiddiqie, bila dicermati hasil Perubahan UUD 1945, ternyata keberadaan MPR dapat dikategorikan sebagai parlemen ketiga (tricameral) (Asshiddiqie, 2004), karena baik MPR, DPR dan DPD memiliki kewenangan dan pimpinan masing-masing, sehingga tidak dapat dikategorikan sebagai sidang gabungan "joint session", melainkan institusi yang berdiri sendiri. Bagir Manan berpandangan ada beberapa pertimbangan bagi Indonesia menuju sistem dua kamar: a) Seperti diutarakan Montesquieu, sistem dua kamar merupakan suatu mekanisme chekcs and balances antara kamar-kamar dalam satu badan perwakilan; b) Penyederhanan sistem badan perwakilan. Hanya ada satu badan perwakilan tingkat pusat yang terdiri dari dua unsur yaitu unsur yang langsung mewakili seluruh rakyat dan unsur yang mewakili daerah. Tidak diperlukan utusan golongan. Kepentingan golongan diwakili dan disalurkan melalui unsur yang langsung mewakili seluruh rakyat; c) Wakil daerah menjadi bagian dari pelaksanaan fungsi parlemen (membentuk undang-undang, mengawasi pemerintah, menetapkan APBN, dan lain-lain). Dengan demikian segala kepentingan daerah terintegrasi dan dapat dilaksanakan sehari-hari dalam kegiatan parlemen. Hal ini merupakan salah satu faktor untuk menguatkan persatuan, menghindari disintegrasi; d) Sistem dua kamar akan lebih produktif. Segala tugas dan wewenang dapat dilakukan setiap unsur. Tidak perlu menunggu atau bergantung pada satu badan seperti sekarang (Manan, 2003).

Berdasarkan pandangan yang demikian, meskipun tidak secara eksplisit dinyatakan menunjukkan bahwa menurut Bagir Manan yang dikehendaki adalah adanya keseimbangan diantara dua kamar dalam parlemen dalam arti strong bicameralism, dan bukan soft bicameralism, sehingga cheks and balances diantara kedua kamar parlemen tersebut akan berjalan dengan baik dalam melaksanakan fungsi konstitusional yang melekat pada lembaga parlemen tersebut, baik fungsi legislasi, fungsi anggaran maupun fungsi pengawasan. Bila diperhatikan ketentuan Pasal 22D Ayat (1) dan (2) UUD Negara Republik Indonesia Tahun 1945 terkait dengan fungsi legislasi, kedudukan DPD bukan dalam konstruksi strong bicameralism bila dibandingkan dengan DPR, sebagaimana diatur dalam Pasal 20 Ayat (1) dan (2) serta Pasal 20A UUD Negara Republik Indonesia Tahun 1945. Dalam hubungan ini, DPR diberi kewenangan sebagai pemegang kekuasaan membentuk undang-undang sejalan dengan fungsi konstitusionalnya di bidang legislasi 
dan anggaran, dan tiap-tiap undang-undang harus memperoleh persetujuan DPR dengan Presiden, tanpa mengikutsertakan DPD, sebagai kamar kedua dalam parlemen (Widitrismiharto, 2007).

Di sisi lain, fungsi legislasi yang melekat pada DPD hanya dengan menggunakan frase "dapat mengajukan kepada DPR" rancangan undang-undang yang berkaitan dengan otonomi daerah, hubungan pusat dan daerah, pembentukan, pemekaran dan penggabungan daerah, pengelolaan sumber daya alam dan sumber daya ekonomi lainnya, serta yang berkaitan dengan perimbangan keuangan pusat dan daerah. Demikian juga dalam pembahasan sebuah rancangan undang-undang, UUD Negara Republik Indonesia Tahun 1945 hanya menggunakan frase "ikut membahas" rancangan undang-undang yang berkaitan dengan otonomi daerah, hubungan pusat dan daerah, pembentukan, pemekaran dan penggabungan daerah, pengelolaan sumber daya alam dan sumber daya ekonomi lainnya, serta yang berkaitan dengan perimbangan keuangan pusat dan daerah, serta memberikan pertimbangan kepada DPR atas rancangan undangundang anggaran pendapatan dan belanja Negara dan rancangan undang-undang yang berkaitan dengan pajak, pendidikan, dan agama, tanpa dilibatkan dalam persetujuan (Surbakti, 2002).

Ketentuan ini menunjukkan adanya dominasi DPR (legislative heavy) terhadap DPD dalam fungsi legislasi, bahkan diksi yang digunakan menunjukkan bahwa pada dasarnya DPD dapat dikatakan tidak memiliki fungsi legislasi yang kuat, karena kewenangan legislasi ada pada DPR dan Presiden, implikasinya bila diperhatikan rancangan undangundang yang dapat diajukan oleh DPD sudah terbatas, dan ternyata juga bukan merupakan kewenangan.

Rumusan UUD Negara Republik Indonesia Tahun 1945 dengan frase DPD "dapat mengajukan" rancangan undang-undang (RUU) bidang tertentu kepada DPR dan dikaitkan dengan frase "ikut membahas", menyebabkan DPD disfungsional (Nurbaningsih, 2015). Dalam kenyataannya aspirasi daerah sulit disalurkan oleh DPD karena Pasal 22D UUD 1945 terkait dengan kewenangan DPD dirumuskan tidak menggunakan diksi yang mengandung norma obligatori, sehingga oleh pembentuk Undang- Undang (DPR dan Presiden), DPD ditafsirkan sebagai "lembaga bantu”, bukan organ utama negara (main state organ) dengan kejelasan fungsinya (Nurbaningsih, 2015). Memperhatikan realitas yang demikian, tentu perlu pemikiran restrukturisasi 
DPR dan DPD sebagai strong bicameralism, baik melalui perubahan lanjutan UndangUndang Dasar maupun melalui peranata hukum peraturan perundang-undangan, khususnya undang-undang tentang pembentukan peraturan perundang-undangan maupun undang-undang tentang MPR, DPR, DPD dan DPRD (UU MD3).

Reformasi konstitusi sebagai salah satu agenda yang timbul seiring dengan tuntutan untuk proses bernegara yang lebih demokratis. Gerakan-gerakan yang berkembang pada waktu itu merupakan suatu wujud kristalisasi keinginan rakyat untuk mengevaluasi kembali kondisi kenegaraan yang berada pada posisi krisis (Subardjo, 2002). Tuntutan reformasi melalui perubahan Undang-Undang Dasar 1945 tersebut telah mengakibatkan banyak terjadinya perubahan dalam sistem ketatanegaraan Republik Indonesia. Salah satu atas perubahan tersebut terjadi dalam hal kelembagaan negara dengan bertambahnya lembaga beberapa lembaga negara, salah satunya adalah Dewan Perwakilan Daerah (DPD) (Soemantri, 2008).

Perubahan Ketiga Undang-Undang Dasar 1945 yang dilaksanakan pada tahun 2001 dalam Sidang Tahunan Majelis Permusyawaratan Rakyat Republik Indonesia, secara yuridis sebagai dasar kehadiran lembaga baru dalam sistem ketatanegaraan di Indonesia yaitu Dewan Perwakilan Daerah Republik Indonesia yang diatur dalam Pasal 22C dan Pasal 22D UUD 1945. DPD sebagai lembaga negara hasil dari rezim reformasi awalnya sebagai lembaga Utusan Daerah di dalam komposisi keanggotaan Majelis Permusyawaratan Rakyat (MPR), yang mana terdiri dari anggota Dewan Perwakilan Rakyat ditambah utusan daerah dan utusan golongan. Kemudian muncul tuntutan agar "Utusan Daerah" dalam MPR diwujudkan dalam bentuk Dewan Perwakilan Daerah (Subardjo, 2002). Sebagai tindaklanjut dari Pasal 22D UUD 1945, pengaturan dalam peraturan perundang-undangan yang berkaitan dengan DPD diatur dalam UndangUndang No.17 Tahun 2014 tentang Majelis Permusyawaratan Rakyat, Dewan Perwakilan Rakyat, Dewan Perwakilan Daerah dan Dewan Perwakilan Rakyat Daerah (UU MD3). UU tersebut merupakan perubahan terhadap Undang-Undang Nomor 27 Tahun 2009 tentang Majelis Permusyawaratan Rakyat, Dewan Perwakilan Rakyat, Dewan Perwakilan Daerah dan Dewan Perwakilan Rakyat Daerah.

Kehadiran DPD sebagai lembaga baru hasil perubahan UUD 1945 merupakan konsekuensi dari perubahan Pasal 1 ayat (2) sebagai upaya untuk mengoptimalkan dan meneguhkan paham kedaulatan rakyat. Ketentuan fungsi bidang legislasi DPD semakin 
diperlemah sebagaimana dalam Pasal 22D ayat (2) UUD 1945. Kritik terbesar dalam fungsi legislasi DPD adalah keterlibatan DPD dibatasi sampai pembahasan Tingkat I. Padahal, UUD 1945 memungkinkan DPD ikut sampai pada proses yang berlangsung di Tingkat II. Secara konstitusional, DPD tidak mungkin ikut memberikan persetujuan terhadap sebuah rancangan undang-undang karena UUD1945 memberikan batasan yang tegas bahwa persetujuan hanya menjadi wewenang DPR dan Presiden. Mahkamah Konstitusi (MK) melalui putusan Mahkamah Nomor 79/PUU-XII/2014 dan Nomor: 92/PUU-X/2012 telah mengembalikan kewenangan DPD yang sebelumnya direduksi oleh UU No. 27 Tahun 2009 tentang MPR, DPR, DPD, dan DPRD (MD3) dan UU No. 12 Tahun 2011 tentang Pembentukan Peraturan Perundang-undangan (P3).

Hal ini disambut baik oleh DPD yang selama ini hanya menjadi bayang-bayang dibawah dominasi DPR; dominasi berlebihan yang mencederai sistem bikameral yang konon dibentuk untuk tujuan mulia yaitu terciptanya sistem check and balance yang baik. Dalam beberapa poin gugatan yang diajukan DPD, 4 (empat) poin diantaranya merupakan pokok eksistensi dan jati diri DPD sebagai lembaga negara yang perlu ditegakkan kembali sebagaimana telah diamanatkan oleh UUD 1945, yaitu: (1) Kewenangan DPD dalam mengajukan RUU setara dengan DPR dan Presiden; (2) Kewenangan DPD ikut membahas RUU; (3) Kewenangan DPD memberikan persetujuan atas RUU; dan (4) Keterlibatan DPD dalam menyusun Prolegnas.

\section{METODE PENELITIAN}

Kerangka teori dalam penelitan hukum memiliki kedudukan penting untuk menganalisis permasalahan yang dikemukakan dalam penelitain sehingga membuat jelas dan terang serta menemukan jawaban atas pertanyaan atau hipotesis atas pertanyaan yang diajukan dalam penelitian. Adapun teori hukum (legal theory) yang relevan dan akan digunakan untuk menganalisis permasalahan delam penelitian ini, adalah teori kepastian hukum (positivisme theory) yang dikemukakan oleh Jhon Austin, teori sistem hukum (legal system theory) yang dikembangkan oleh Fridman, teori kontirusi, teori kedaulatan dan teori pembatasan kekuasaan. Jhon Austin, merumuskan kepastian hukum sebagai perintah penguasa, dalam arti bahwa perintah dari mereka yang memegang kekuasaan tertinggi atau yang memegang kedaulatan. Dengan demikian, dapat dikatakan bahwa teori ini hanya bersumber pada hukum yang tertulis yang 
disahkan oleh kekuasaan pemerintah atau suatu negara. Dengan kata lain, wujud kepastian hukum menurut teori ini umumnya berupa peraturan tertulis yang dibuat oleh suatu badan yang mempunyai otoritas.

Kepastian hukum mengharuskan terciptanya suatu peraturan umum atau kaidah umum yang berlaku secara umum, serta mengakibatkan bahwa tugas hukum umum untuk mencapai kepastian hukum (demi adanya ketertiban dan keadilan bagi seluruh rakyat Indonesia). Hal ini dilakukan agar terciptannya suatu yang aman dan tentram dalam masyarakat luas dan ditegakkannya serta dilaksanakannya dengan tegas Teori Konstitusi dipilih karena sebagai paham dan semangat (spirit) memiliki tujuan untuk membatasi tindakan sewenang-wenang pemerintah, menjamin hak-hak pihak yang diperintah (rakya) dan menetapkan pelaksanaan kekuasaan yang berdalat. Sehingga pada hakekatnya tujuan kosntitusi merupakan perwujudan paham tentang konstitusionalisme yang berarti pembahasan terhadap kekuasaan pemerintah disatu pihak dan jaminan terhadap hak-hak warga negara maupun setiap penduduk pihak lain.

Dalam berbagai literatur hukum tata negara maupun ilmu politik ditegaskan bahwa fungsi konstitusi adalah sebagai dokumen nasional dan alat membentuk syistem politik dan hukum negara. Oleh katena itu ruang lingkup undang-undang dasar sebagai konstitusi tertulis sebagaimana dikemukakan oleh A.A.HY Struycken memuat tentang : a) Hasil perjuangan politik bangsa diwaktu lampau; b) Tingkat-tingakt tinggi pembangunan ketatanegaraan bangsa; c) Pandangan tokoh bangas yang hendak diwujudkan, baik sekarang maupun masa yang akan datang; d) Suatu keinginan yang mana perkembangan kehidupan tetanegaraan bangsa hendak dipimpin. Kontitusi merupakan bagian dan terciptannya kehidupan yang demokrasi bagi seluruh warga negara.

Jika negara yang memilih demokrasi, maka kontitusi demokrasi merupakan atuaran yang dapat menjamin terwujudnya demokrasi dinegara tersebut. Setiap kontitusi yang digolongkan sebgai kontitusi demokrasi haruslah memiliki prinsi-prinsip demokrasi itu sendiri. Teori kedaulatan rakyat dipilih sebagai Grand Theory. Dipilihnya teori ini karena dapat menjelaskan secara filosofis tentang konsep politik yang bersifat makro tentang letak kedaulatan dan akan dijelaskan juga sejarah transformasinya di dalam praktek ketatanegaraan. Teori kedaulatan rakyat mengajarkan bahwa yang sesungguhnya berdaulat dalam negara adalah rakyat yang merupakan ciri negara hukum atau negara demokrasi konstitusional. 
Vol 2, No. 2, Desember 2019, DOI: https://doi.org/10.34007/iehss.v2i2.103

Dalam literatur ilmu hukum atau ilmu politik, kata kedaulatan berasal dari kata soverighty (bahasa Inggris), souverainete (bahasa Prancis), sovranus (bahasa Italia). Kata-kata asing tersebut diturunkan dari kata latin superanus yang berarti "yang tertinggi" (supreme). Menurut Jimly Asshiddiqie, bahwa kedaulatan merupakan konsep mengenai kekuasaan tertinggi dalam penyelenggaraan negara. Kata "daulat" dan "kedaulatan" berasal dari kata Arab daulah yang berarti rezim politik atau kekuasaan. Negara Indonesia menganut paham kedaulatan rakyat (democratie). Pemilik kekuasaan tertinggi yang sesungguhnya dalam negara Indonesia adalah rakyat. kekuasaan itu harus didasari berasal dari rakyat, oleh rakyat dan untuk rakyat. Bahkan, kekuasaan hendaklah diselenggarakan bersama-sama dengan rakyat.

Dalam sistem konstitusional berdasarkan Undang-Undang Dasar, pelaksanaan kedaulatan rakyat disalurkan dan diselenggarakan prosedur konstirusional menurut hukum dan konstitusi (constitutional democracy). Dengan kata lain bahwa teori kedaulatan rakyat merupakan cikal bakal yang melahirkan sistem demokrasi yang dikenal saat ini dikenal sebagai sitem pemerintahan negara modern. Pada awalnya, gagasan demokrasi dilakukan secara langsung. Kemudian muncuk konsep yang dinamakan demokrasi tidak langsung atau perwakilan dimana penyelenggaraan pemerintahan maupun lembaga negara dipilih oleh rakyat. Dengan demikian, rakyat tidak lagi terlibat secara langsung dalam proses pemerintahan negara. Wakil rakyat tersebut bertindak mewakili dan mengikuti atau mewujudkan aspirasi rakyat dalam sebuah lembaga perwakilan.

Teori kedua yang digunakan dalam penelitian ini adalah Teori Pembatasan Kekuasaan. Salah satu ciri negara hukum (the rule of law atau rechtsstaat) ditandai dengan pembatasan kekuasaan dalam penyelenggaraan kekuasaan negara. Pembatasan ini dilakukan dengan hukum yang kemudian menjadi ide dasar paham konstitusionalisme modern. Sebagaimana Julius Stahl menyatakan, pembagian atau pemisahan kekuasaan adalah salah satu elemen penting teori negara hukum Eropa Kontinental. Pembatasan kekuasaan biasanya diwujudkan melalui dua pilihan cara, yaitu sistem pemisahan kekuasaan (separation of power) dan pembagian kekuasaan (distribution of power).

Pemisahan kekuasaan bersifat horizontal dalam arti kekuasaan dipisah-pisahkan ke dalam fungsi-fungsi yang tercermin dalam lembaga-lembaga negara yang sederajat 
dan saling mengimbangi (checks and balances). Sedangkan, pembagian kekuasaan bersifat vertikal dalam arti perwujudan kekuasaan itu dibagikan secara vertikal ke bawah kepada lembaga-lembaga negara dibawah lembaga memegang kekuasaan negara. Konsep pemisahan kekuasaan yang dikemukakan John Locke dikembangkan oleh Baron de Monstesquieu dalam karyanya L'Espirit des Lois (The Spirit of the Laws).

Dalam uraiannya, Montesquieu membagi kekuasaan pemerintahan dalam tiga cabang, yaitu kekuasaan membuat undang-undang (legislatif), kekuasaan untuk menyelenggarakan undang-undang yang oleh Montesquieu diutamakan tindakan dibidang politik luar negeri (eksekutif) dan kekuasaan mengadili terhadap pelanggaran undang-undang (yudikatif). Kekuasaan itu harus terpisah satu sama lain, baik mengenai tugas (fungsi) maupun mengenai alat kelengkapan (lembaga) yang menyelenggarakannya, konsepsi yang dikembangkan Montesquieu lebih dikenal dengan ajaran Trias Politica.

Jika dibandingkan konsep pembagian kekuasaan John Locke (1632-1704) dan Montesquieu (1689-1785), perbedaan mendasar pemikiran keduanya, bahwa John Locke memasukkan kekuasaan yudikatif ke dalam kekuasaan eksekutif, sedangkan Montesquieu memandang kekuasaan yudikatif berdiri sendiri. Berbeda halnya dengan pemikiran John Locke dan Montesquieu, seorang sarjana Belanda Van Vollenhoven, mengemukakan bahwa tugas dalam sebuah negara itu bukan tiga, tetapi empat cabang kekuasaan dengan memakai Kwartas Politica (Catur Praja), yang mana memasukkan tugas polisionil sebagai tugas memelihara ketertiban masyarakat dan bernegara. Secara umum, pemisahan kekuasaan dalam bahasa Indonesia dimaknai (separation of power) dimulai dari pemahaman atas teori Trias Politica Montesquieu.

Hal ini muncul dari pemahaman pendapat Montesquieu yang menyatakan "when the legislative and the executive powers are united in the same person, or in the sama body of magistrate, there can be no liberty". Pandangan Montesquieu memberikan pengaruh yang sangat luas dalam pemikiran kekuasaan negara. Pendapat Montesquieu yang dikutipkan dimaknai, bahwa cabang-cabang kekuasaan negara benarbenar terpisah atau tidak mempunyai hubungan sama sekali. Teori Penguatan atau reinforcement theory of motivation dikemukakan oleh B.F. Skinner pada tahun (19041990) dan para rekan-rekannya, pandangan mereka menyatakan bahwa prilaku individu merupakan fungsi dari konsekuensi-konsekuaensi (rangsangan, respon dan 
konsekuensi). Teori ini didasarkan atas semacam hukum pengaruh dimana tingkah laku dengan konsekuensi positif cenderung untuk diulang. Sementara tingkah laku denan konsekuensi negatif cenderang untuk tidak diulang. Teori ini berfokus sepenuhnya pada apa yang terjadi pada seorang individu ketika ia bertindak, teori ini adalah alat yang kuat untuk menganalisis mekanisme pengendalian untuperilaku individu. Namun, tidak fokus pada penyebab perilaku individu. Menurut Skinner lingkungan eksternal organisasi harus dirancang secara efektif dan posisti sehingga dapat memotivasi karyawan. Model penguatan Skinner adalah interval (tetap atau Variabel) dan Rasio (tetap atau Variabel). Penguatan terus menerus, pemberian secara konstan penguatan terhadap tindakan, dimana setiap kali tindakan tertentu dilakukan, diberikan terhadap subjek secara langsung dan selalu menerima penguatan, metode

ini tidak praktis untuk digunakan dan perilaku diperkuat rentan terhadap kepunahan. Interval (fixed/ variabel) penguatan tetap, penguatan mengikuti respon pertama setelah durasi yang ditetapkan, variabel waktu yang harus dilalui sebelum respon menghasilkan penguatan tidak diatur tetapi bervariasi di sekitar nilai ratarata. Rasio (tetap atau variabel) penguatan tetap sejumlah tanggapan harus terjadi sebelum ada penguatan. Variabel jumlah tanggapan senbelumnya penguatan disampaikan berbeda dari yang terakhir namum memiliki nilai rata-rata. Implikasi teori penguatan mirip dengan teeori keseimbangan yang membangun kesadaran yang lebih luas terhadap dimensi penilaian masing-masing individu sebagai manifestasi keadilan. Dan teori penguatan menjelaskan secara rinci bagaimana seseorang belajar berprilaku.

\section{HASIL DAN PEMBAHASAN}

\section{Analisa terhadap Putusan Mahkamah Konstitusi}

Berdasarkan dengan apa yang telah dijabarkan tentang DPD RI baik itu tentang sejarah terbentuknya lembaga tersebut sampai kepada wewenang yang dimilikinya sesuai amanat Undang-Undang Dasar Negara Republik Indonesia tahun 1945 (UUD NRI) maka dapat dianalisa bahwasannya dalam menjalankan tugas pokok dan fungsinya sebagai lembaga legislative tidaklah mudah, banyak sekali hambatan yang dirasakan seiring dengan perkembangan politik yang terjadi, bahkan sering kali dikatakan bahwasannya keberadaan lembaga negara Dewan Perwakilan Daerah ini sebagai Dewan 
Pertimbangan yang dibutuhkan oleh Dewan Perwakilan Rakyat (DPR) saja. Seperti yang telah diketahui bersama, lembaga Dewan Perwakilan Daerah (DPD) ini memiliki 3 tugas pokok dan fungsi yakni dalam bidang legislasi, pertimbangan dan pengawasan.

Secara signifikan untuk kewenangan dalam bidang pertimbangan dan pengawasan tidak ditemukan adanya persoalan atau hambatan yang mendasar, hambatan atau persoalan justru timbul pada kewenangan DPD RI dalam bidang legislasi, DPD RI memang sejatinya tidak mempunyai kewenangan yang cukup berarti dalam hal ini ruang gerak DPD RI dalam bidang legislasi terbatas pada keadaan tertentu saja. Selain diatur dalam Undang-Undang Dasar Negara Republik Indonesia tahun 1945 (UUD NRI), tugas pokok dan fungsi yang dimiliki oleh lembaga Dewan Perwakilan Daerah ini juga diatur dalam Undang- undang No. 27 tahun 2009 tentang MPR, DPR dan DPD, dan DPRD (UU MD3) yang sekarang telah diperbaharui dengan Undang-Undang No. 17 tahun 2014 tentang MPR, DPR dan DPD, dan DPRD (UU MD3). Sebelum Undang-Undang No. 17 tahun 2014 tentang MPR, DPR dan DPD, dan DPRD (UU MD3) disahkan dan ditetapkan, banyak sekali polemik yang terjadi di dalamnya, seperti yang telah dijabarkan sebelumnya bahwa pada Undang-Undang tersebut dalam beberapa pasalnya telah mereduksi kewenangan dari lembaga Dewan Perwakilan Daerah itu sendiri.

Kewenangan yang terbatas dimiliki oleh Dewan Perwakilan Daerah ini semakin dipersempit dengan adanya Undang-Undang tersebut sebelum direvisi seperti saat ini, sebelumnya dikatakan dalam Undang- Undang tersebut bahwasannya Dewan Perwakilan Daerah hanya mempunyai kewenangan mengajukan RUU pada bidang tertentu dan ikut membahasnya hanya pada tingkat pertama bahkan RUU yang diajukan oleh Dewan Perwakilan Daerah ini jika disetujui oleh Dewan Perwakilan Rakyat (DPR) maka ketika dilanjutkan ke proses tahap berikutnya dalam hal ini pembahasan, maka RUU tersebut berubah menjadi RUU yang diusulkan oleh Dewan Perwakilan Rakyat (DPR). Hal yang demikianlah yang menjadi salah satu penyebab mengapa Review Dewan Perwakilan Daerah mengajukan Yudisial kepada Mahkamah Konstitusi sesuai dengan kewenangannya yakni satu-satunya lembaga yang dapat memberikan tafsiran UndangUndang Dasar Negara Republik Indonesia tahun 1945 (UUD NRI) serta lembaga yang dapat menguji Undang-Undang terhadap UUD NRI tahun 1945.

Jika dilihat dari sepanjang perjalanan DPD RI dalam menjalankan tupoksinya (tugas pokok dan fungsi) hal ini juga tidak sesuai ekspektasi yang diharapkan mengingat awal 
terbentuk dan tujuan yang ingin dicapai dengan adanya lembaga ini. Lahirnya UndangUndang no 27 tahun 2009 tentang MD3 juga semakin memperkecil dan mereduksi kewenangan dari lembaga DPD yang sebenarnya sebagai lembaga legislative. Atas dasar tersebut DPD RI lalu melakukan pengujian Formil dan Materiil atas Undang-Undang No. 27 Tahun 2009 ke Mahkamah Konstitusi dengan harapan untuk mengembalikan kewenangan DPD dalam bidang legislasi sebagaimana yang diatur dalam UUD NRI tahun 1945.Pada tanggal 21 Desember 2013 Mahkamah Konstitusi sebagai lembaga negara yang berwenenang lantas mengeluarkan Putusan Nomor 92/PUU-X/2012 dan mengabulkan permohonan untuk sebagian itu Menegaskan kembali kewenangan konstitusi DPD dalam bidang legislasi.

Putusan Mahkamah Konstitusi Nomor 92/PUU-X/2012 cukup memberikan perubahan pola legislasi DPD RI secara signifikan. Dalam putusannya, dapat dilihat bahwasannya kedudukan DPD RI tersebut di bidang legislasi tidak lagi sebagai subordinat Dewan Perwakilan Rakyat (DPR), melainkan kedudukannya menjadi setara dengan DPR dan Presiden sebagaimana yang diatur UUD NRI tahun 1945. Selanjutnya, DPD RI juga berhak dan/atau berwenang untuk mengusulkan dan membahas RUU tertentu sejak awal hingga akhir tahapan, namun kewenangan DPD RI tersebut tetaplah berhenti pada tahap proses akhir yakni tahap persetujuan atau pengesahan RUU menjadi undang-undang (UU).

Hal ini dikarenakan secara eksplisit memang nyatanya UUD NRI tahun 1945 telah membatasi ketentuan mengenai hal tersebut. Mahkamah Konstitusi juga memutuskan bahwa DPD ikut menyusun program legislasi nasional (prolegnas). Namun yang terjadi adalah lahirnya UU No. 17 Tahun 2014 tentang MD3 yang di bentuk pasca adanya Putusan Mahkamah Kostitusi yang merupakan pengganti dari UU No. 27 Tahun 2009 Tentang MD3, tetap saja memuat ketentuan pasal-pasal yang tetap mereduksi, menegasikan, bahkan mengikis kewenangan konstitusional yang dimiliki oleh DPD RI sebagaimana telah ditegaskan juga oleh Putusan Mahkamah Konstitusi. Hal ini menunjukkan bahwasannya pembentuk UU MD3 dalam hal ini adalah DPR RI dan MPR RI dinilai tidak menghargai dan menghormati adanya putusan Mahkamah Konstitusi Nomor 92/PUU- X/2012 tersebut.

Artinya Mahkamah Konstitusi sesuai dengan amanat UUD NRI tahun 1945 yang diberi kewenangan sebagai lembaga penafsir stitutione of con konstitusim (interpret) 
dan menjaga konstitusi (guardian), tidak dihormati oleh para pembentuk UU MD3 tersebut. Dalam UU No. 17 Tahun 2014 Tentang MD3, kewenangan konstitusional DPD RI untuk ikut serta dalam proses pembentukan UU ditiadakan dalam UU tersebut. Padahal seharusnya dalam hal mangajukan itution of const RUU dan membahas RUU MD3 harus mengikutsertakan lembaga DPD RI karena isi dari UU tersebut berkaitan tentang pembahasan kedudukan, susunan dan kewenangan dari lembaga DPD RI itu sendiri.

Hal ini sebagaimana telah tertulis dalam Putusan Mahkamah Konstitusi Nomor 92/PUU-X/2012 yang telah menafsirkan Pasal 22D aya t(1) dan (2) UUD 1945 Yang berisi bahwasannya UUD NRI tahun 1945 memberikan kedudukan DPD setara dengan Presiden dan DPR. Maka dengan pengesampingan keberadaan lembaga DPD RI dalam proses tahapan pengajuan serta pembahasan UU MD3 dapat dikatakan sebagai pelanggaran terhadap UUD NRI 1945. Sebab itu pulalah yang membuat lembaga DPD RI lagi-lagi mengajukan uji formil dan materil terhadap Undang-Undang tersebut (Yudisial Review) dalam hal ini adalah UU No. 17 Tahun 2014 Tentang MD3 untuk mempertegas kedudukan serta kewenangan dari lembaga DPD RI untuk kedua kalinya.

Dan akhirnya pada tanggal 29 September 2014, untuk kedua kalinya Mahkamah Konstitusi mengeluarkan putusannya akan perkara tersebut dengan nomor register Putusan Mahkamah Konstitusi nomor 79 PUU_XII/2014 yang berisi bahwasannya putusan ini memperkuat dari isi putusan sebelumnya yakni mengembalikan kewenangan DPD RI sebagaimana mestinya sesuai dengan apa yang telah diamanatkan oleh UUD NRI tahun 1945. Maka dari itu dapat disimpulkan bahwasannya kewenangan DPD RI yang tertuang dalam putusan Mahkamah Konstitusi nomor 79/PUU_XII/2014 adalah kewenangan dalam bidang legislasi dalam hal ini DPD RI sebagai lembaga legislatif diberikan wewenang adalah kedudukan DPD RI dalam bidang legislasi setara dengan DPR dan Presiden, atas dasar itu pula DPD RI berhak dan/atau berwenang mengusulkan RUU tertentu saja yaitu berwenang untuk menyusun Program Legislasi Nasional (Prolegnas) di lingkungan DPD RI dan membahas RUU tertentu saja, sejak awal hingga akhir tahapan proses pembentukan UU tersebut, namun DPD RI disini tidak berwenang untuk memberikan persetujuan atau pengesahan RUU menjadi undangundang. Berdasarkan hal tersbut dapat dilihat bahwasannya kewenangan DPD RI dalam putusan tersebut telah sesuai dengan apa yang diamanatkan oleh UUD NRI tahun 1945 
dan diharapkan dalam tindakan rill yang dilakukan DPD RI dalam menjalankan wewenang dapat berjalan sesuai dengan yang telah ditentukan oleh UUD NRI tahun 1945 dan putusan MK no 79/PUU_XII/2014.

\section{Dilema DPD RI Pasca Putusan Mahkamah Konstitusi}

Saat ini dialektika tentang keberadaan DPD RI secara khusus dan konstruksi sistem lembaga perwakilan Indonesia pada umumnya kembali menjadi diskursus yang menghangat. Sebelumnya DPD RI telah mengajukan permohonan uji materi kepada Mahkamah Konstitusi yakni lewat permohonan Nomor 79/PUU-XII/2014 yang diajukan tanggal 15 Agustus 2014, salah satunya mengenai Pasal 174 ayat (1) UU 17/2014 dianggap bertentangan dengan Bab VIIA Dewan Perwakilan Daerah, Pasal 22C dan Pasal 22D UUD 1945 karena mengelabui kewenangan dan tugas DPD RI. Pada kesempatan ini, peneliti mencoba mengintisarikan menjadi beberapa item hasil ketetapan dan putusan MK yang saya yakini akan menjadi topik seksi dan hangat didialektikakan diloronglorong diskusi publik, terutama topik yang berkaitan penataan kembali sistem perwakilan Indonesia. Bisa jadi wacana ini akan berujung pada kuatnya arus untuk melakukan amandemen kelima UUD 1945 secara komprehensif. Inilah beberapa item ketetapan dan putusan MK terkait Uji Materi yang diajukan oleh DPD RI, terutama dalam norma Pasal 174 ayat (1) :Menurut Mahkamah norma Pasal 174 ayat (1) Undang-Undang a quo mengenai pertimbangan DPD atas rancangan undang-undang anggaran pendapatan dan belanja negara dan rancangan undang-undang yang berkaitan dengan pajak, pendidikan, dan agama disampaikan sebelum memasuki tahapan pembahasan antara DPR dan Presiden adalah sudah tepat sebab kewenangan DPD atas rancangan undang-undang tersebut hanya sebatas memberikan pertimbangan dan tidak ikut membahas rancangan undang-undang, sehingga tidak ada relevansinya sama sekali apabila pertimbangan DPD tersebut diberikan pada saat pembahasan antara DPR dan Presiden sebagaimana yang dimohonkan oleh Pemohon. UUD 1945 sengaja membedakan antara pertimbangan dengan persetujuan. 
Indonesia tidak Menganut Sistem Bikameral sesuai dengan Bentuk Negara Indonesia yaitu Negara Kesatuan.

Lembaga perwakilan di Indonesia menurut UUD 1945, juga tidak mengenal majelis tinggi dan majelis rendah. Baik DPR maupun DPD adalah lembaga perwakilan yang tugas, wewenang, dan fungsinya telah ditentukan dalam UUD 1945. DPR merupakan representasi perwakilan rakyat, sedangkan DPD adalah representasi perwakilan daerah. Secara historis, DPD tidak pernah dirancang dan diniatkan sebagai senat seperti misalnya yang dikenal di Amerika Serikat bahkan negara tetangga seperti Filipina dan negara-negara lainnya yg berada di dunia. Oleh sebab itu, anggota DPD bukanlah senator.

Tugas, wewenang dan fungsi DPD sama sekali berbeda dengan tugas, wewenang, dan fungsi senat dalam lembaga perwakilan yang merupakan model bikameral. Secara historis, kelahiran DPD adalah perluasan tugas, wewenang, dan fungsi utusan daerah yang dikenal pada masa sebelum dilakukan perubahan UUD 1945. Karena itu, namanya sempat diusulkan sebagai Dewan Utusan Daerah. Semangat yang melandasi pembentukan DPD adalah semangat memperkuat negara kesatuan Republik Indonesia yaitu dengan cara memberikan kewenangan kepada wakil-wakil daerah (anggota DPD) untuk turut ambil bagian dalam pengambilan putusan politik tertentu sepanjang berkenaan dengan daerah.

Menurut penulis dalam penelitian ini hampir semua item diatas, hasil Keputusan Mahkamah Konstitusi yang putusannya final dan mengikat menjadi sebuah bumerang bagi lembaga dan anggota DPD RI ditengah upaya dan usahanya dalam memperkuat keberadaan dan wewenang DPD RI. Apalagi beberapa istilah seperti senator dan bikameralisme dilingkungan DPD RI sebelum ini gencar disosialisasikan. Tetapi apa yang menjadi hasil keputusan MK bak menampar wajah para wakil-wakil daerah, tanpa dinafikan secara elektabilitas dan otoritas keterwakilannya sangat besar daripada anggota DPR RI, karena untuk menjadi anggota DPD RI jumlah dan luas daerah pemilihannya lebih besar dari anggota DPR RI.

Bola panas telah diputus dan digulirkan oleh MK, anggota DPD RI tentu tidak akan mendiamkan begitu saja semua ini, jika kembali mengajukan Uji Materi kepada MK rasanya sudah semakin muskil dan menambah jurang bunuh diri. Jalan terakhir menurut penulis hanya dua cara, pertama tiada lain berusaha kembali mengakumulasi tenaga dan pikiran untuk meyakinkan MPR RI dan segenap elemen bangsa untuk 
melakukan amandemen kelima UUD 1945. Inipun hasilnya juga penuh misteri, bisa jadi hasil keputusan MK akan menjadi tangga kuat bagi kamar sebelah DPR RI untuk semakin mendegradasi keberadaan DPD RI atau malah mengembalikan DPD RI seperti utusan daerah saat UUD 1945 sebelum diamandemen.

Cara kedua, DPD RI mengubur jauh-jauh upaya penguatan kewenangan lembaga DPD RI, saatnya segala sumberdaya dan idealisme mewakili daerah untuk memajukan bangsa dan negara dengan fokus mengerjakan tugas-tugas keparlemenan sepanjang amanat yang sudah digariskan dalam konstitusi. Disamping selalu mencoba mencari cara lain untuk melihatkan eksistsensi dan keberadaan lembaga dan anggota DPD RI dirasakan kehadirannya ditengah-tengah masyarakat dan daerah.

\section{SIMPULAN}

Pelaksanaan Fungsi Legeslasi Dewan Perwakilan Daerah (DPD) dalam Pembahasan RUU Menurut Pasal 22C dan 22D UUD 1945. Ada tiga kewenangan DPD yang bersinggungan dengan DPR, Pemerintah Daerah, dan Presiden secara bersamaan; yaitu, pertama kewenangan DPD untuk mengajukan kepada DPR RUU yang berkaitan dengan otonomi daerah, hubungan pusat dan daerah, pembentukan, pemekaran, dan penggabungan daerah, pengelolaan sumber daya alam dan sumber daya ekonomi lainnya, serta perimbangan keuangan pusat dan daerah. Kedua, kewenangan DPD dalam proses pembahasan dan pertimbangan atas RUU. Ketiga, kewenangan DPD dalam pengawasan atas pelaksanaan Undang-undang, DPD pada dasarnya tidak memegang kekuasaan untuk membentuk UU. DPD hanya dapat mengajukan UU kepada DPR. Dengan demikian DPD tidak mempunyai hak inisiatif mandiri dalam pembuatan UU. Dengan demikian, DPD tidaklah mempunyai 'kekuatan konstitusional'untuk berkompetisi. Karena DPD sesungguhnya tidak mempunyai wewenang sampai pada tingkat pengambilan keputusan termasuk dalam proses legislasi. DPD selaku lembaga negara dalam sistem bikam eral diformulasikan sebagai lembaga perwakilan rakyat yang secara kelembagaan memiliki kedudukan sama dengan DPR, bahkan dari segi karakter keterwakilan berdasarkan daerah-daerah, DPD memiliki karakter keterwakilan yang lebih luas dari DPR, karena dimensi keterwakilannya didasarkan kepada seluruh rakyat yang terdapat pada daerah-daerah. DPD selaku lembaga perwakilan rakyat memiliki tugas dan wewenang sebagaimana DPR, yaitu memiliki fungsi anggaran, legislasi dan 
pengawasan meski sifatnya terbatas. Dalam konteks ketatanegaraan Indonesia, tidak ada sinkronisasi dan harmonisasi fungsi DPD dan DPR. Keadaan ini melemahkan fungsi DPD selaku lembaga negara, dibidang fungsi legislasi DPD tidak memiliki zelfstandigheid, karena DPD hanya sebatas sebagai lembaga yang mengajukan RUU, dibidang fungsi pengawasan hasil pengawasan DPD tidak dilanjuti oleh DPD sendiri tetapi disampaikan kepada DPR, sehingga DPR lah yang menentukan hasil pengawasan DPD tersebut ditindaklanjuti atau tidak. Kewenangan Legislasi DPD RI yang tertuang dalam putusan Mahkamah Konstitusi nomor 79/PUU ?XII/2014 adalah DPD RI berhak dan/atau berwenang mengusulkan RUU, DPD juga berwenang untuk menyusun Program Legislasi Nasional (Prolegnas) sesuai bidang atau ruang lingkup dari DPD RI dan ikut pula membahas RUU tersebut secara penuh baik pembahasan pertama maupun pembhasan tahap kedua kecuali dalam tahap persetujuan RUU tersebut.

\section{DAFTAR PUSTAKA}

Asshiddiqie, J, (2004), Format Kelembagaan Negara dan Pergeseran Kekuasaan dalam UUD 1945, FH UII Press, Yogyakarta.

Asshiddiqie, J, (2005), Konstitusi dan Konstitusionalisme, (Jakarta, Konstitusi Press

Asshiddiqie, J, (2005). Format Kelembagaan Negara dan Pergeseran Kekuasaan dalam UUD 1945. Yogyakarta: FH UII Press

Asshiddiqie, J, (2006), Pengantar Ilmu Hukum Tata Negara: Jilid II, Jakarta: Sekretariat Jenderal dan Kepaniteraan RI.

Asshiddiqie, J, (2007), Pokok-Pokok Hukum Tata Negara Pasca Reformasi, Jakarta: Bhuana Ilmu Populer

Asshiddiqie, J, (2010). Perkembangan dan Konsolidasi Lembaga Negara Pasca Reformasi. Jakarta: Sinar Grafika

https://empimuslion.wordpress.com/2015/10/01/dilema-dpd-ri pasca-putusan-mk/ 30 Juni 2019

Majalah Konstitusi, Memperkuat Kewenangan DPD, Konstitusi, Edisi April 2013 No.74, Sekretariat Mahkamah Konstitusi Republik Indonesia, Jakarta

Manan, B, (2003), Teori dan Politik Konstitusi, FH UII Press, Yogyakarta.

Bakar, M. 1987, Kedaulatan Rakyat dan Implementasinya Setelah Dekrit Presiden 5 Juli 1959, Tesis, Program Pascasarjana UNPAD, Bandung.

Mimbar Hukum, Volume 27 Nomor 1, Februari 2015

Mochtar, Z.A. \& Isra, S. (Ed.), (2009), Jalan Berliku Amandemen Komprehensif dari Pakar, Politisi, hingga Selebriti,

Nurbaningsih, E, (2015), Implikasi Putusan Mahkamah Konstitusi Nomor 92/PUU-X/2012 dan Alternatif Model Hubungan Terkait Pembentukan Undang-Undang

Perilakuorganisasi.com/teori-penguatan/html.better understanding of self and others in oeganizational context 02/01/2019 18:32

Pigome, M. (2011). “Implementasi Prinsip Demokrasi dan Nomokrasi dalam Struktur Ketatanegaraan RI.

Raharjo, S, (2007), Ilmu Hukum, Bandung: citra Aditya Bakti

Rasjidi. L. (2004), Dasar-dasar Filsafat dan Teori Hukum, PT. Citra Adiya Bakti, Bandung

Salinan Putusan Mahkamah Konstitusi No.92/PUU-X/2012 Tentang MPR, DPR, DPD \& DPRD

Siahaan, P. (2012). Politik Hukum Pembentukan Undang-Undang Pasca Amandemen UUD 1945, Jakarta: Konpress.

Soekanto, S, (1983), Penegakan Hukum, Binacipta, Bandung

Soemantri, S. (2008). "Lembaga Negara dan State Auxiliary Bodies dalam Sistem Ketatanegaraan Menurut UUD 1945". Majalah Hukum Nasional Nomor 1 Tahun 2008 
Subardjo, (2002), Dewan Perwakilan Daerah: Menurut Undang-Undang Dasar Negara Republik Indonesia Tahun 1945 dan Penerapan Sistem Bikameral dalam Lembaga Perwakilan Indonesia, Yogyakarta: Graha Ilmu

Surbakti, R. (2002). “Menuju Demokrasi Konstitusional: Reformasi Hubungan dan Distribusi Kekuasaan”, dalam Maruto MD dan Anwari WMK (eds.). Reformasi Politik dan Kekuatan Masyarakat, Kendala dan Peluang Menuju Demokrasi. Jakarta: LP3ES

Up-date09.blogspot.com/2012/11/makalah-konsepdasar-kontitusi.html/ tanggal 31/1/2019.11

Widitrismiharto, D. (2007). "Kedudukan Dewan Perwakilan Daerah Republik Indonesia yang Setara dan Seimbang dalam Sistem Ketatanegaraan Indonesia”. Jurnal Yustika Volume 10 Nomor 1 Tahun 2007 Yamin, M, (1971), Naskah Persiapan Undang-Undang Dasar 1945, Yayasan Prapanca, Jakarta 